\title{
PERSEPSI DAN SIKAP IBU HAMIL TERHADAP PEMANFAATAN \\ PELAYANAN ANTE NATAL CARE (ANC) OLEH BIDAN DI WILAYAH I PUSKESMAS KABUPATEN LEBAK TAHUN 2016
}

\author{
* Yayah Rokayah, *Siti Rusyanti
}

\begin{abstract}
Abstrak
Menurut KepMenPAN Nomor 58 Tahun 2002 menyatakan ada tiga jenis pelayanan, salah satunya yaitu pelayanan jasa yang diberikan oleh penyedia layanan yang bersentuhan langsung kepada masyarakat, diantaranya pelayanan asuhan kebidanan pada ibu hamil berupa pelayanan Antenatal Care.

Persepsi masyarakat terhadap suatu layanan merupakan suatu tolok ukur untuk menigkatkan kualitas pelayanan yang pada akhirnya akan membentuk kepuasan pelanggan. Hasil penelitian Saputri Reni (2009) tentang persepsi masyarakat terhadap pelayanan kesehatan sebagian besar persepsi masyarakat dalam kategori cukup $(52,5 \%)$. Penelitian ini bertujuan mengetahui persepsi dan sikap ibu hamil terhadap pemanfaatan pelayanan ANC oleh bidan di wilayah I Puskesmas Kabupaten Lebak.

Desain penelitian dilakukan dengan pendekatan Cross sectional. Besar sampel sebanyak 100 responden, populasinya ibu hamil yang mendapatkan pelayanan ANC oleh bidan. Analisis data menggunakan uji Chi Square.

Hasil analisis univariat sebagian besar $94.0 \%$ ibu hamil mempunyai persepsi baik terhadap pemanfaatan pelayanan ANC oleh bidan, sebesar $66.0 \%$ sikap ibu hamil terhadap pemanfaatan layanan ANC oleh bidan adalah baik, dan pemanfaatan layanan ANC yang diberikan oleh bidan sebagian besar $71.0 \%$ adalah baik. Hasil analisis bivariat pada variable persepsi didapatkan nilai $P$ 1,000 maka tidak ada hubungan yang signifikan antara persepsi dengan pemanfaatan pelayanan ANC oleh bidan, penelitian ini sejalan dengan Lukiono (2011) bahwa pemanfaatan pelayanan kesehatan di puskesmas tidak dipengaruhi oleh persepsi masyarakat atas mutu pelayanan kesehatan. Pada variable sikap didapatkan nilai $P 0.122$, maka tidak ada hubungan yang signifikan antara sikap dengan pemanfaatan pelayanan ANC oleh bidan, pernyataan ini sesuai Notoatmodjo (2008) bahwa sikap seseorang yang baik tidak bisa menjamin untuk bisa berprilaku yang positif dalam pemanfaatan pelayanan kesehatan.

Bidan hendaknya lebih meningkatkan lagi kualitas dalam memberikan pelayanan ANC terutama keterampilan komunikasi, karena komunikasi dapat meningkatkan pengetahuan, pemahaman dan perubahan prilaku ibu hamil dalam melakukan perawatan kehamilan. Ibu hamil hendaknya membagikan pengalaman positif tentang perawatan kehamilan kepada ibu-ibu yang lain.
\end{abstract}

Kata Kunci: Persepsi, Sikap, Ibu Hamil, ANC, Bidan.

*) Dosen Jurusan Kebidanan Poltekkes Kemenkes Banten 


\title{
PERCEPTION AND ATTITUDE OF PREGNANT WOMEN TO USE THE SERVICE ANTE NATAL CARE (ANC) BY THE MIDWIFE IN HEALTH REGION I KABUPATEN LEBAK 2016
}

\author{
* Yayah Rokayah, **Siti Rusyanti
}

\begin{abstract}
According to the Ministerial PAN No. 58 of 2002 states there are three types of services, one of which services provided by a service provider in direct contact to the public, including midwifery care services for pregnant women such as Antenatal Care services.

The public perception of a service is a benchmark for improving the quality of service that will ultimately form the customer satisfaction. The results of the study Saputri Reni (2009) on community perceptions of health services in the public perception largely enough category (52.5\%). This study aims to find out the perceptions and attitudes of pregnant women on the utilization of ANC by midwives in the region I Puskesmas Lebak.

The study design is done with cross sectional. The sample size of 100 respondents, the population of pregnant women who received ANC by a midwife. Data analysis using Chi Square test.

Results of univariate analysis majority of $94.0 \%$ of pregnant women have a good perception on the utilization of ANC by midwives, amounting to $66.0 \%$ of pregnant mother's attitude towards the utilization of antenatal care by midwives is good, and the utilization of antenatal care provided by midwives majority of $71.0 \%$ is good. The results of the bivariate analysis on the perception variable values obtained $\mathrm{P}$ 1,000 then there is no significant relationship between perception and utilization of ANC by midwives, are consistent with Lukiono (2011) that the utilization of health services in clinics were not influenced by the public perception on the quality of health services. In the variable $\mathrm{P}$ value 0.122 obtained attitude, then there is no significant relationship between attitudes to the use of ANC by midwives, according Notoatmodjo this statement (2008) that the attitude of someone who either can not vouch for the positive could behave in the utilization of health services.

Midwives should further enhance the quality in providing service ANC especially communication skills, because communication can improve knowledge, understanding and changing behavior of pregnant women in prenatal care. Pregnant women should share the positive experience of prenatal care to others.
\end{abstract}

Keywords: Perception, Attitudes, pregnant women, ANC, Midwives

*,**) Lecturer Jurusan Kebidanan Poltekkes Kemenkes Banten 


\section{Pendahuluan}

Menurut Keputusan Menteri Pemberdayaan Aparatur Negara (KepMen PAN) Nomor 58 Tahun 2002 yang menyatakan ada tiga jenis pelayanan, salah satunya yaitu pelayanan jasa yang diberikan oleh penyedia layanan yang bersentuhan langsung kepada masyarakat, diantaranya pelayanan asuhan kebidanan pada ibu hamil berupa pelayanan Antenatal Care.

Pemanfaatan pelayanan kesehatan adalah hasil dari proses pencarian pelayanan kesehatan oleh seseorang maupun kelompok. Menurut Notoatmodjo (2007), perilaku pencari pengobatan adalah perilaku individu maupun kelompok atau penduduk untuk melakukan atau mencari pengobatan. Perilaku pencarian pengobatan di masyarakat terutama di negara sedang berkembang sangat bervariasi. Banyak pendapat yang menyebutkan faktor-faktor yang mempengaruhi pemanfaatan pelayanan kesehatan seperti yang diungkapkan oleh Departement Of Education and Welfare, USA (1997) dan Lapau (1997), yaitu (1) faktor dari sistem pelayanan kesehatan yang bersangkutan, (2) faktor adanya fasilitas kesehatan lain, (3) faktor dari konsumen yang menggunakan pelayanan kesehatan yaitu faktor sosiodemografi (meliputi umur, jenis kelamin dan status perkawinan), faktor sosial psikologis (meliputi sikap, persepsi terhadap pelayanan kesehatan secara umum, pengetahuan dan sumber informasi dari pelayanan kesehatan, faktor ekonomi dan kemudahan menjangkau pelayanan kesehatan. Masyarakat saat ini sudah semakin selektif dalam memilih pelayanan kesehatan, sehingga diperlukan suatu pelayanan berkualitas yang memungkinkan masyarakat untuk menggunakan pelayanan tersebut, sehingga pemanfaatannya menjadi tinggi.

Persepsi dan sikap masyarakat terhadap suatu layanan merupakan suatu tolok ukur untuk meningkatkan kualitas pelayanan yang pada akhirnya akan membentuk kepuasan pelanggan. Hasil penelitian Saputri Reni (2009) tentang persepsi masyarakat terhadap pelayanan kesehatan, sebagian besar persepsi masyarakat dalam kategori cukup $(52,5 \%)$.

Ibu hamil akan merasa puas apabila kinerja layanan kesehatan khususnya ANC yang diperolehnya sama atau melebihi harapannya dan sebaliknya, ketidakpuasan akan muncul apabila layanan kesehatan khususnya ANC yang diperolehnya tidak sesuai dengan harapannya. Tingkat kepuasan pasien dapat diukur secara kualitatif dan kuantitatif. Jika akan melakukan upaya peningkatan mutu pelayanan, pengukuran tingkat kepuasan pasien ini mutlak diperlukan. Melalui pengukuran tersebut, dapat diketahui sejauh mana dimensi-dimensi mutu layanan yang 
telah dilakukan dapat memenuhi harapan pasien. Hal ini akan sangat mempengaruhi terhadap pemanfaatan pelayanan ANC oleh bidan.

\section{Metode}

Penelitian ini dirancang menggunakan metode survei dengan pendekatan cross sectional. Populasi yang dijadikan sebagai subyek penelitian adalah semua ibu hamil yang mendapatkan pelayanan ANC oleh bidan di wilayah I Puskesmas Kabupaten Lebak sebanyak 4.860 orang. Kriteria inklusi pemilihan sampel penelitian adalah pernah diberikan asuhan kebidanan ANC oleh bidan di wilayah I Puskesmas Kabupaten Lebak dan bersedia menjadi responden penelitian. Besar sampel 100 orang.

Jenis data adalah data primer yang diperoleh dengan menggunakan metode wawancara langsung berdasarkan kuesioner. Dilakukan analisis data univariat dan bivariat. Analisis data univariat dilakukan dengan mendeskripsikan semua variabel penelitian dalam bentuk tabel distribusi frekuensi. Analisis data bivariat Dilakukan untuk menjawab hipotesis penelitian dengan menggunakan uji Chi Square. Analisis tersebut dianggap bermakna jika $\mathrm{p}$ value $\leq 0,05$, Ho ditolak dan Ha diterima yang berarti ada hubungan antara dua variabel tersebut. p value $>0,05$,
Ho diterima dan Ha ditolak yang berarti tidak ada hubungan antara dua variabel.

\section{Hasil}

1. Analisis Univariat

a. Persepsi Ibu Hamil Terhadap Pelayanan ANC oleh Bidan

Persepsi responden tentang pemanfaatan pelayanan ANC oleh bidan dalam penelitian ini dibedakan dalam kategori persepsi kurang yaitu responden yang bisa menjawab pertanyaan $\leq 85 \%$ Serta persepsi baik yaitu responden yang bisa menjawab pertanyaan $\geq 85 \%$ Distribusi persepsi responden dapat dilihat pada tabel berikut ini:

Tabel 1.

Distribusi Frekuensi Persepsi Ibu Hamil Terhadap Pelayanan ANC oleh Bidan

\begin{tabular}{lcc}
\hline Persepsi ibu hamil & F & $\%$ \\
\hline Baik & 94 & 94.0 \\
Kurang & 6 & 6.0 \\
\hline Jumlah & 100 & 100 \\
\hline
\end{tabular}

Berdasarkan persepsi responden pada tabel 1 dapat diketahui bahwa sebagian besar $94.0 \%$ ibu hamil mempunyai persepsi baik terhadap pemanfaatan pelayanan ANC yang diberikan oleh bidan.

b. Sikap Ibu Hamil Terhadap Pelayanan ANC oleh Bidan.

Sikap responden terhadap pemanfaatan pelayanan ANC oleh bidan dalam penelitian ini dibedakan dalam 
kategori sikap kurang yaitu responden yang bisa menjawab pertanyaan $\leq 45 \%$ Serta sikap baik yaitu responden yang bisa menjawab pertanyaan $\geq 45 \%$. Distribusi persepsi responden dapat dilihat pada tabel berikut ini:

Tabel 2.

Distribusi Frekuensi sikap Ibu Hamil Terhadap Pelayanan ANC oleh Bidan

\begin{tabular}{lcc}
\hline Sikap ibu hamil & F & $\%$ \\
\hline Baik & 65 & 65.0 \\
Kurang & 35 & 35.0 \\
\hline Jumlah & 100 & 100 \\
\hline
\end{tabular}

Berdasarkan sikap responden pada tabel 2 dapat diketahui bahwa sebesar $66.0 \%$ sikap ibu hamil terhadap pemanfaatan layanan ANC oleh bidan adalah baik dan sisanya $34.0 \%$ ibu hamil mempunyai sikap tidak baik terhadap pemanfaatan pelayanan ANC oleh bidan.

c. Pemanfaatan Pelayanan ANC oleh bidan.

Pemanfaatan pelayanan ANC yang diberikan oleh bidan dalam penelitian ini dibedakan dalam kategori kurang jika pelayanan ANC yang diberikan oleh bidan tidak sesuai keinginan ibu hamil, dan baik jika pelayanan ANC yang diberikan oleh bidan sesuai keinginan ibu hamil. Distribusi persepsi responden dapat dilihat pada tabel berikut ini:
Tabel 3.

Distribusi Frekuensi Pemanfaatan Pelayanan ANC oleh bidan.

\begin{tabular}{lcc}
\hline $\begin{array}{l}\text { Pemanfaatan } \\
\text { pelayanan ANC }\end{array}$ & $\mathrm{F}$ & $\%$ \\
\hline Baik & 71 & 71.0 \\
\hline Kurang & 29 & 29.0 \\
\hline Jumlah & 100 & 100 \\
\hline
\end{tabular}

Berdasarkan Pemanfaatan pelayanan ANC pada tabel 3 dapat diketahui bahwa pemanfaatan layanan ANC yang diberikan oleh bidan sebagian sebesar $71.0 \%$ adalah baik (pelayanan ANC yang diberikan oleh bidan sesuai keinginan ibu hamil) dan sisanya $29.0 \%$ mengatakan kurang baik (pelayanan ANC yang diberikan oleh bidan tidak sesuai keinginan ibu hamil).

\section{Analisis Bivariat}

Analisis bivariat dilakukan menggunakan uji chi square. Tabel-tabel berikut ini menyajikan hasil analisis bivariat antara variabel, persepsi dan Sikap ibu hamil dengan variabel pemanfaatan pelayanan ANC oleh bidan. 
a. Hubungan Antara Persepsi Ibu Hamil Dengan Pemanfaatan Pelayanan ANC Oleh Bidan.

Tabel 4.

Hubungan Antara Persepsi ibu hamil dengan pemanfaatan pelayanan ANC oleh bidan

\begin{tabular}{|c|c|c|c|c|c|c|}
\hline \multirow{3}{*}{ Persepsi } & \multicolumn{4}{|c|}{ Pemanfatan ANC } & \multirow{2}{*}{\multicolumn{2}{|c|}{ Total }} \\
\hline & \multicolumn{2}{|c|}{ kurang } & \multicolumn{2}{|c|}{ Baik } & & \\
\hline & $\mathrm{n}$ & $\%$ & $\mathrm{n}$ & $\%$ & $\mathrm{n}$ & $\%$ \\
\hline Kurang & 4 & 66,7 & 2 & 33,3 & 6 & 100 \\
\hline Baik & 67 & 71,3 & 27 & 28,7 & 94 & 100 \\
\hline Total & 71 & 71.0 & 29 & 29.0 & 100 & 100 \\
\hline
\end{tabular}

Berdasarkan tabel silang 4 diketahui bahwa hasil analisis bivariat dengan uji chi square nilai $P$ 0,809 . Dapat diartikan bahwa tidak ada hubungan yang signifikan antara persepsi ibu hamil dengan pemanfaatan pelayanan ANC yang diberikan oleh bidan.

b. Hubungan Antara Sikap Ibu Hamil Dengan pemanfaatan Pelayanan ANC Oleh Bidan.

Tabel 5.

Hubungan Antara Sikap ibu hamil dengan pemanfaatan pelayanan ANC oleh bidan

\begin{tabular}{ccccccc}
\hline \multirow{2}{*}{ Sikap } & \multicolumn{4}{c}{ Pemanfatan ANC } & \multicolumn{2}{c}{ Total } \\
\cline { 2 - 6 } & \multicolumn{2}{c}{ kurang } & \multicolumn{2}{c}{ baik } & \multicolumn{2}{c}{ Ton } \\
\cline { 2 - 6 } & $\mathrm{n}$ & $\%$ & $\mathrm{n}$ & $\%$ & $\mathrm{n}$ & $\%$ \\
\hline Kurang & 21 & 60.0 & 14 & 40.0 & 35 & 100 \\
\hline Baik & 50 & 76.9 & 15 & 23.1 & 65 & 100 \\
\hline Total & 1 & 71.0 & 29 & 29.0 & 100 & 100 \\
\hline
\end{tabular}

Berdasarkan tabel silang 5 diketahui hasil analisis bivariat dengan uji chi square didapatkan nilai $P \quad 0.75$ maka dapat diartikan bahwa tidak ada hubungan yang signifikan antara sikap ibu hamil dengan pemanfaatan pelayanan ANC yang diberikan oleh bidan.

\section{Pembahasan}

Analisis Univariat

\section{Persepsi}

Berdasarkan data yang didapat dari hasil penelitian menunjukan bahwa persepsi ibu hamil terhadap pemanfaatan layanan ANC oleh bidan sebagian sebesar $94.0 \%$ adalah baik dan $6.0 \%$ kategori kurang baik, yang berarti bahwa ibu hamil yang mempuyai persepsi baik lebih besar dibandingkan ibu hamil yang mempunyai persepsi kurang baik. Hal ini menunjukan bahwa pemanfaatan pelayanan kesehatan bisa dipengaruhi oleh persepsi seseorang tentang baik tidaknya layanan kesehatan.yang diberikan, selanjutnya persepsi seseorang terhadap pemanfaatan pelayanan bisa dipengaruhi dari penngalaman seseorang pada saat menerima pelayanan kesehatan. Pernyataan ini sesuai dengan teori yang dikemukakan oleh Andersen dan Newman (1995), bahwa salah satu faktor yang bisa mempengaruhi pemanfaatan pelayanan kesehatan adalah persepsi seseorang tentang mutu suatu pelayanan kesehatan. 
Menurut Safitri persepsi merupakan proses informasi yang berasal dari pengalaman dan peristiwa yang terjadi pada masa lampau. Pengalaman ibu hamil dalam melakukan pemeriksaan kehamilan sebelumnya akan berpengaruh tehadap persepsi dan perilaku ibu dalam melakukan pemeriksaan kehamilan yang sekarang. Ibu yang mendapatkan pengalaman yang kurang menyenangkan pada saat melakukan pemeriksaan pada kehamilan sebelumnya akan cenderung kurang antusias dalam melakukan pemeriksaan kehamilan, karena takut pengalaman yang lalu akan terulang kembali.

\section{Sikap}

Dari hasil penelitian di dapatkan bahwa sikap ibu hamil terhadap pemanfaatan layanan ANC oleh bidan sebagian sebesar $66.0 \%$ adalah baik dan $34.0 \%$ kurang baik. Ini menunjukan bahwa ibu hamil yang mempunyai sikap baik cenderung lebih besar dibandingkan dengan yang kurang, karena sikap merupakan hal yang penting dalam kehidupan sehari-hari, bila sikap itu sudah terbentuk dalam diri seseorang selanjutnya akan ikut menentukan tingkah lakunya terhadap sesuatu. Sikap yang utuh dipengaruhi oleh pengetahuan, keyakinan dan emosi seseorang. Menurut penelitian Irna (2010), mengatakan sikap akan berpengaruh kepada seseorang untuk melakukan suatu tindakan oleh kenyakinan dan juga pemahaman tentang tindakan itu sendiri, sikap merupakan reaksi yang tidak tampak yang merupakan kesiapan atau kesedian untuk bertindak. Dan menurut L.Green, mengatakan bahwa sikap merupakan reaksi atau respon yang masih tertutup dari seseorang terhadap stimulus atau obyek. Sikap hal yang penting dalam kehidupan sehari-hari, bila sikap sudah terbentuk dalam diri seseorang selanjutnya akan ikut menentukan perilakunya terhadap sesuatu.

3. Pemanfaatan Pelayanan ANC oleh Bidan

Dari hasil penelitian diketahui bahwa pemanfaatan pelayanan ANC yang diberikan oleh bidan sebagian sebesar $71.0 \%$ adalah baik (pelayanan ANC yang diberikan oleh bidan sesuai keinginan ibu hamil) dan 29.0\% kurang baik (pelayanan ANC yang diberikan oleh bidan tidak sesuai keinginan ibu hamil). Ini meunjukkan bahwa responden yang mengatakan baik terhadap pelayanan ANC oleh bidan lebih besar dibanding responden yang mengatakan kurang baik terhadap pelayanan ANC oleh bidan, akan tetapi pemanfaatan pelayanan ANC oleh bidan tetap perlu mendapatkan perhatikan karena rendahnya pengetahuan ibu hamil tentang perawatan kehamilan dapat disebabkan karena kurangnya informasi yang diberikan 
oleh bidan pada saat pelayanan antenatal, dan pengalaman ibu hamil dalam melakukan pemeriksaan kehamilan sebelumnya akan berpengaruh tehadap perilaku ibu dalam melakukan pemeriksaan kehamilan yang sekarang. Pernyataan ini sesuai dengan teori Depkes (2008) yang menyatkan bahwa Ibu yang mendapatkan pengalaman yang kurang menyenangkan pada saat melakukan pemeriksaan pada kehamilan sebelumnya akan cenderung kurang antusias dalam melakukan pemeriksaan kehamilan, karena takut pengalaman yang lalu akan terulang kembali.

\section{Analisis Bivariat}

Analisis bivariat dilakukan menggunakan uji chi square. berikut ini menyajikan hasil analisis bivariat antara variabel, persepsi dan Sikap ibu hamil dengan variabel pemanfaatan pelayanan ANC oleh bidan.

\section{Hubungan Antara Persepsi Ibu Hamil Dengan Pemanfaatan Pelayanan ANC Oleh Bidan}

Dari hasil analisis bivariat dengan uji chi square didapatkan nilai p 1,000 sehingga dapat diartikan bahwa tidak ada hubungan yang signifikan antara persepsi ibu hamil dengan pemanfaatan pelayanan ANC yang diberikan oleh bidan. Artinya orang yang mempunyai persepsi baik tidak menjamin untuk berprilaku positif, karena persepsi bukan salah factor yang berpengruh terhadap pemanfaatan pelayanan kesehatan, karena untuk menentukan prilaku seseorang terhadap pelayanan kesehatan bisa ditentukan oleh faktor lainnya yang berpengaruh seperti pengetahuan, pengalaman, fasilitas pelayanan, dukungan keluarga, jangkauan pelayanan, tradisi, nilai dll. Pernyataan ini tidak sesuai dengan teori Andersen dan Newman (1995), yang mengatakan bahwa salah satu faktor yang bisa mempengaruhi pemanfaatan pelayanan kesehatan adalah persepsi seseorang tentang mutu suatu pelayanan kesehatan. Namun penelitian ini sejalan dengan penelitian Lukiono (2011) bahwasanya pemanfaatan pelayanan kesehatan di puskesmas tidak dipengaruhi oleh persepsi masyarakat atas mutu pelayanan kesehatan yang meliputi fasilitas, sikap petugas, dan kesulitan akses, dan menurut Notoadmodjo, 2010 bahwa perilaku kesehatan seseorang ditentukan antara lain oleh ada atau tidaknya dukungan masyarakat sekitarnya (social support). Orang yang tinggal di lingkungan yang menjunjung tinggi aspek kesehatan akan lebih antusias dalam menjaga kesehatannya. Sebaliknya mereka yang tinggal dilingkungan dengan pola hidup tidak sehat atau tidak memperhatikan kesehatan akan cenderung tidak perduli dengan pencegahan 
penyakit atau pemeriksan kesehatan secara teratur.

2. Hubungan Antara Sikap Ibu Hamil Dengan Pemanfaatan Pelayanan ANC Oleh Bidan.

Dari hasil analisis bivariat dengan uji chi square didapatkan nilai $P 0.122$ maka dapat diartikan bahwa tidak ada hubungan yang signifikan antara sikap ibu hamil dengan pemanfaatan pelayanan ANC yang diberikan oleh bidan. Hal ini menunjukan bahwa sikap bukan merupakan faktor yang berpengaruh terhadap pemanfaatan pelayanan ANC oleh bidan karena ada faktor lain yang berpengaruh seperti pengalaman, fasilitas pelayanan, jangkauan pelayanan, sosial budaya, dukunga keluarga dll. Hasil penelitian ini tidak sesuai dengan penelitian Irna (2010), yang mengatakan bahwa sikap akan berpengaruh kepada seseorang untuk melakukan suatu tindakan dalam memanfaatkan pelayanan kesehatan. Dan menurut teori L.Green sikap merupakan reaksi atau respon yang masih tertutup dari seseorang terhadap stimulus atau obyek. Sikap hal yang penting dalam kehidupan sehari-hari, bila sikap sudah terbentuk dalam diri seseorang selanjutnya akan ikut menentukan perilakunya terhadap sesuatu. Namun penelitian ini sesuai dengan teori yang dikemukakan oleh Notoatmodjo (2008) bahwa sikap seseorang yang baik atau positif tidak bisa menjamin seseorang untuk bisa berprilaku yang positif dalam pemanfaatan pelayanan kesehatan.

\section{Daftar Pustaka}

Asihani D, Hubungan Antara Persepsi Dan Sikap Ibu Hamil Tentang Ante Natal Care Dengan Kunjungan Pemeriksaan Kehamilan di Rumah Bersalin Permata Bunda Sragen. Tesis. 2010.

Depkes RI, Pedoman Program Perencanaan dan Pencegahan Stiker dalam Rangka Mempercepat penurunan AKI. Departemen Kesehatan. Jakarta, 2002.

-----------, Faktor yang Mempengaruhi Kunjungan Pemeriksaan ANC. Jakarta, 2008.

Green LW. Health Promotion Planning An Educational and Environmental Approach. USA: Mayfield Publishing Company, 2000

Kurniati T. Ilmu Kesehatan masyarakat untuk kebidanan. Jakarta, 2010.

Lukiono, Persepsi Dan Pemanfaatan Pelayanan Kesehatan Di Puskesmas Oleh Keluarga Penerima Jamkesmas.Jurnal Kesehatan Vol.7 no 1, Maret 2015. Medika Majapahit. Mojokerto

Modul peatihan Acuan Midwifery Update. IBI 2016

Notoatmodjo. Ilmu Prilaku . Rineka Cipta. Jakarta 2007.

Notoatmodjo. Ilmu Prilaku dan Aplikasinya. Rineka Cipta. Jakarta 2010. 
Notoatmodjo. Ilmu Prilaku Dan Pendidikan. Rineka Cipta. Jakarta 2005.

Notoatmodjo. Metodologi Penelitian kesehatan. Rineka Cipta. Jakarta 2003.

Pohan, Imbalo S, Jaminan Mutu Layanan Kesehatan. EGC. Jakarta. 2006.

Prawirohardjo,S. Ilmu Kebidanan ECG. Jakarta, 2014.

Rahmah, N, Pengaruh Pengetahuan, Sikap dan Motivasi Terhadap Minat Bidan Mengikuti Uji Kompetensi Di Kota Semarang. Tesis, TAHUN 2007.

Santosa, H, Persepsi Masyarakat terhadap Kualitas Pelayanan Kesehatan di Puskesmas Binjai Kota, Departemen Kependudukan dan Biostatistika Fakultas Kesehatan Masyarakat Universitas Sumatera Utara, 2007.

Saryono, Metodologi Penelitian Kesehatan, Mitra Cendikia Press. Jogjakarta. 2011.

Siyoto, Sandu., Persepsi dan Pemanfaatan Pelayanan Kesehatan di Puskesmas Oleh Keluarga Penerima Jamkesmas. Medika Majapahit, Jurnal Ilmiah Kesehatan, Vol.7 No. 1.2015

Sunarsih, Y, Kualitas Pelayanan Kesehatan dengan Tingkat Kepuasan Pasien di Klinik Terpadu Poltekkes Tanjungkarang, Jurusan Keperawatan Poltekkes Kemenkes Tangjungkarang, 2013.

Tando, Naomie M., Mutu Layanan Kebidanan dan Kebijakan Kesehatan. IN MEDIA. 2013.

Varney H. Buku Saku Bidan. ECG. Jakarta, 2002.
Watugigir, S.Z, Hubungan Pengetahuan dan Sikap Ibu Hamil Tentang Antenatal care Dengan Penggunaan Buku KIA Di Wilayah Kerja Puskesmas Ranotana Wamena Manado. Tesis 2014. 